\title{
Single Step Microwave Assisted Synthesis and Antimicrobial Activity of Silver, Copper and Silver-Copper Nanoparticles
}

\author{
Myrna Reyes-Blas $^{{ }^{*}}{ }^{(\mathbb{C}}$, Nadja M. Maldonado-Luna ${ }^{2}$, Carla M. Rivera-Quiñones ${ }^{3}$, \\ Ana L. Vega-Avila1, Felix R. Roman-Velázquez¹, Oscar J. Perales-Perez ${ }^{1,4}$ \\ ${ }^{1}$ Department of Chemistry, University of Puerto Rico at Mayagüez, Mayaguez, USA \\ ${ }^{2}$ Department of Mechanical Engineering, University of Puerto Rico at Mayagüez, Mayaguez, USA \\ ${ }^{3}$ Department of Chemical Engineering, University of Puerto Rico at Mayagüez, Mayaguez, USA \\ ${ }^{4}$ Department of Engineering Science \& Materials, University of Puerto Rico at Mayagüez, Mayaguez, USA \\ Email: *myrna.reyes@upr.edu
}

How to cite this paper: Reyes-Blas, M., Maldonado-Luna, N.M., Rivera-Quiñones, C.M., Vega-Avila, A.L., Roman-Velázquez, F.R. and Perales-Perez, O.J. (2020) Single Step Microwave Assisted Synthesis and Antimicrobial Activity of Silver, Copper and Silver-Copper Nanoparticles. Journal of Materials Science and Chemical Engineering, 8, 13-29.

https://doi.org/10.4236/msce.2020.88002

Received: July 7, 2020

Accepted: August 15, 2020

Published: August 18, 2020

Copyright $\odot 2020$ by author(s) and Scientific Research Publishing Inc. This work is licensed under the Creative Commons Attribution International License (CC BY 4.0).

http://creativecommons.org/licenses/by/4.0/

\begin{abstract}
Copper and silver nanoparticles were synthesized and characterized in two minutes at $175^{\circ} \mathrm{C}$ in a one-step synthesis using a modified polyol (ethylene glycol) method and a microwave heating process. We successfully synthesized spherical Silver $(\mathrm{Ag})$ and Copper nanoparticles (CuNP) with a crystallite size of less than $10 \mathrm{~nm}$, as well as irregular silver-copper nanoparticles (AgCuNP) with a crystallite size of less than $15 \mathrm{~nm}$, as confirmed by X-Ray Diffraction (XRD) and High-Resolution Transmission Electron Microscopy (HRTEM). The successful synthesis of AgCuNP with 1:1 molar ratio and constituted by $51.74 \%$ of copper and $48.26 \%$ of silver was corroborated using the Energy Dispersive X-ray (EDX) mapping technique. The AgNP and AgCuNP exhibited more stability in suspension, in comparison to CuNP, as observed by continuously monitoring the absorbance with UV-Vis spectroscopy for 12 days. Furthermore, the minimum inhibitory concentration (MIC) and minimum bactericidal concentration (MBC) of AgNP, CuNP, and AgCuNP were determined, against Gram-negative and Gram-positive bacteria, and yeast. The obtained MIC and MBC values indicate that $\mathrm{AgCu}$ nanoparticles exhibited bactericidal properties greater than its constituents. On the contrary, antifungal activity of AgCuNP against yeast was not observed.
\end{abstract}

\section{Keywords}

Ag Nanoparticles, Cu Nanoparticles, Microwave Synthesis, Modified Polyol Method, Antimicrobial Properties, AgCu Nanoparticles 


\section{Introduction}

Bacterial infections are an increasing public health concern. Most illnesses caused by bacteria are associated with the consumption of infected fresh products. The U.S. Center for Disease Control and Prevention (CDC) estimates that forty-eight million people get sick from a foodborne illness each year [1], meaning, that microbial pathogens are responsible for one of the leading causes of life-threatening illnesses around the world. Consequently, food safety is a public health issue of great concern to individual consumers, industries, and regulatory authorities. Among the most common foodborne disease-causing bacteria, in the United States, are Salmonella, Escherichia coli (E. coli), and Staphylococcus aureus ( $S$. aureus) [2]. The consumption of food contaminated with these pathogenic bacteria could cause diarrhea, abdominal cramps and nausea. However, it could also lead to chronic illnesses such as cancer, brain and neural disorders, kidney and liver failure [3]. The risk of human bacterial infections caused by these microorganisms remains a challenge as these often survive on surfaces as a biofilm and have generated an enhanced resistance over time to commonly used antimicrobial agents [4] [5] [6]. Various techniques are traditionally used to extend the shelf life of food products, such as pickling, drying and freezing, and thermal processing. However, most nutrients in food are denaturalized or destroyed as a result of these procedures [7]. Hence, research on non-thermal sterilization techniques has become the foundation of research in this field. In this context, the attention has been focused on the production of novel nanoparticle-based materials with enhanced antimicrobial properties [8] [9] [10] [11]. Nanomaterials have long been of interest in various fields of biomedical and agricultural research, as these exhibit unique characteristics compared to conventional macroscopic materials [12] [13]. It is well-known that Silver ( $\mathrm{Ag})$ is a potent antimicrobial agent whose properties have been exploited to inhibit bacterial growth and destroy the cellular structure of microorganisms [10] [14] [15] [16]. Likewise, Copper $(\mathrm{Cu})$ is also recognized as a potent antibacterial agent [17]. In this paper, we present a two minutes single step microwave assisted synthesis of $\mathrm{Ag}, \mathrm{Cu}$, and $\mathrm{AgCu}$ nanoparticles (NPs) produced using a modified polyol method. This synthesis route provides an enhanced alternative to conventional synthesis method as it leads to the formation of smaller and monodisperse metallic nanoparticles in a shorter time, thus decreasing the use and quantity of toxic reagents. UV-Vis analyses were carried out to confirm the presence of $\mathrm{Ag}$ and $\mathrm{Cu}$ in the nanoparticles. The NPs were characterized in terms of crystallinity through XRD, and morphology and nanoparticle size distribution by HRTEM. The antibacterial activity of the nanoparticles was tested against E. coli, Salmonella and $S$. Aureus, all of which are well known to be responsible of the most common foodborne illnesses. The nanoparticles were also tested against C.albicans to evaluate the nanoparticles effects against yeast. Although, the antibacterial properties of silver and copper nanoparticles have been extensively documented, this work evidences that $\mathrm{AgCu}$ bimetallic nanoparticles show a great- 
er antibacterial effect when compared to Ag and $\mathrm{Cu}$ NPs by itself.

\section{Materials and Methods}

\subsection{Optimum Temperature Co-Reduction Synthesis of Silver and Copper Nanoparticles}

A modified polyol method was used to determine the optimum temperature of reduction (i.e. single $\mathrm{Cu}$ and AgNPs). Using ethylene glycol (anhydrous, 99.8\%, Sigma-Aldrich) as solvent. The reaction mixture was prepared with Sodium Chloride $0.6 \mu \mathrm{M}$ (ACS, $\geq 99 \%$, Sigma-Aldrich), polyvinylpyrrolidone $0.005 \mu \mathrm{M}$ (average mol wt 40,000, Sigma-Aldrich), Sodium Hydroxide 0.8 M (ACS Reagent, Sigma-Aldrich) and Silver Nitrate $1.6 \mu \mathrm{M}$ (ACS, $\geq 99 \%$, Sigma-Aldrich) to synthesize AgNP. Alternatively, for the CuNP synthesis, Copper Acetate $1.6 \mu \mathrm{M}$ (99.99\%, Sigma-Aldrich) was added to the mixture, instead of Silver Nitrate. The solutions were heated for $2 \mathrm{~min}$ at $155^{\circ} \mathrm{C}, 160^{\circ} \mathrm{C}, 165^{\circ} \mathrm{C}, 170^{\circ} \mathrm{C}, 175^{\circ} \mathrm{C}$, and $180^{\circ} \mathrm{C}$ in a Teflon vessel using a laboratory microwave furnace Mars 6 Xtraction, CEM with a power of $1000 \mathrm{~W}$. The nanoparticles were coagulated using 2-propanol (Certified ACS; $\geq 99.5$ Fisher Scientific) and dried for subsequent characterization.

\subsection{Synthesis of Silver-Copper Nanoparticles}

The co-reduction of Silver-Copper (so-called $\mathrm{AgCu}$ ) were synthesized preparing a mixture of Sodium Chloride $1.2 \mu \mathrm{M}$ (ACS, $\geq 99 \%$, Sigma-Aldrich), polyvinylpyrrolidone $0.01 \mu \mathrm{M}$ (average mol wt 40,000, Sigma-Aldrich), Sodium Hydroxide 1.6 M (ACS Reagent, Sigma-Aldrich), Silver Nitrate $1.6 \mu \mathrm{M}$ (ACS, $\geq 99 \%$, Sigma-Aldrich), and Copper Acetate $1.6 \mu \mathrm{M}$ (99.99\%, Sigma-Aldrich), using ethylene glycol (anhydrous, 99.8\%, Sigma-Aldrich) as the solvent, resulting in an $\mathrm{Ag}: \mathrm{Cu}=1: 1$ molar ratio solution. The synthesis was performed in a laboratory microwave furnace Mars6 Xtraction, CEM with a power of $1000 \mathrm{~W}$ for $2 \mathrm{~min}$ at $175^{\circ} \mathrm{C}$. The obtained nanoparticles were coagulated using 2-propanol (Certified ACS; $\geq 99.5$ Fisher Scientific).

\subsection{Characterization Techniques}

The crystal structure properties of the synthesized $\mathrm{Ag}, \mathrm{Cu}$, and $\mathrm{AgCu}$ nanoparticles were determined using powder X-ray diffraction (XRD, SIEMENS D 500 diffractometer with $\mathrm{Cu}-\mathrm{Ka}$ radiation). For the AgCuNP, the crystalline structure was corroborated using a Rigaku XtalLab Supernova single-crystal X-ray Diffraction system with single micro-focus $\mathrm{Cu}$ source and Hypix Hybrid Array detection. The optical properties were analyzed performed UV-Vis absorption measurements using a Beckman DU 800 Spectrophotometer. The particle morphology and size distribution were determined by HRTEM (JEOL-2011 and JEM-ARM200F units). Elemental composition analysis of the AgCuNP was conducted using Energy Dispersive Spectroscopy (EDS) with an EDAX Si(Li) 30 $\mathrm{mm}^{2}$ energy dispersive X-ray spectroscopy detector. 


\subsection{Stability Test of Silver, Copper Nanoparticles and Copper-Silver Nanoalloy}

To evaluate the stability of nanoparticles in suspension through time, the $\mathrm{UV}$-Vis absorption properties of $\mathrm{Ag}, \mathrm{Cu}$, and $\mathrm{AgCu}$ nanoparticles, synthesized at $175^{\circ} \mathrm{C}$, in ethylene glycol were monitored every 24 hours for a period of 12 days. For AgNP, a characteristic plasmon peak was expected to be observed around $400 \mathrm{~nm}$, and for $\mathrm{Cu}$ nanoparticles around $650 \mathrm{~nm}$. Measurements were performed using a Beckman DU 800 Spectrophotometer.

\subsection{Antimicrobial Assays}

The antimicrobial capability of $\mathrm{Ag}, \mathrm{Cu}$ and $\mathrm{AgCu}$ nanoparticles was evaluated against Gram-negative bacteria, Escherichia coli (ATCC 25922) and Salmonella typhimurium (ATCC 14020), Gram-positive bacteria Staphylococcus aureus (ATCC 25923), and a yeast, Candida albicans (ATCC 10211) using a broth microdilution method to determine the minimum inhibitory concentration (MIC) [18]. For this assay, nanoparticle suspensions at different concentrations (20 to $2200 \mu \mathrm{g} / \mathrm{mL}$ ) were evaluated in 96-well microplates with a bacterial suspension of about $10^{6} \mathrm{CFU} / \mathrm{mL}$, incubated under agitation at $37^{\circ} \mathrm{C}$ for $24 \mathrm{~h}$. After the incubation period, a resazurin dye solution was added to the well plates and incubated at $37^{\circ} \mathrm{C}$ for an additional $2 \mathrm{~h}$. The MIC was qualitatively determined by the smallest concentration of nanoparticle at which the blue colored solution remained unchanged [19] [20].

To determine the minimum bactericidal concentration (MBC) [21], from each nanoparticle concentration for which absolute inhibition was observed, $1 \mu \mathrm{L}$ of suspension was used to inoculate selective agar plates and incubate at $37^{\circ} \mathrm{C}$ for $24 \mathrm{~h}$. The MBC was determined as the nanoparticle concentration at which no bacterial growth was observed on the agar plate. The selective agars used were MacConkey Agar for Escherichia coli (E. Coli), SS Agar for Salmonella typhimurium (Salmonella), Baird Parker Agar for Staphylococcus aureus (S. aureus), and Sabdex Agar for Candida albicans (C. albicans).

\section{Results and Discussion}

\subsection{Determination of Optimum AgCu Nanoalloys Synthesis Temperature}

In order to establish the optimal temperature parameters, $\mathrm{Cu}, \mathrm{Ag}$ and $\mathrm{AgCu}$ nanoparticles were synthesized at different temperatures ranging from $155^{\circ} \mathrm{C}$ to $180^{\circ} \mathrm{C}$. Following the synthesis of the nanoparticles, UV-Vis analyses were carried out to confirm the presence of $\mathrm{Ag}$ and $\mathrm{Cu}$ metals in the nanoparticles. The UV-Vis absorption spectrum recorded for the silver nanoparticles (shown in Figure 1(b)), synthesized at temperatures $155^{\circ}$ to $180^{\circ}$ exhibited a maximum absorption peak at $406 \mathrm{~nm}$ attributed to the plasmon resonance characteristic of silver nanoparticles. UV-Vis analyses showed broader and red-shifted peaks at higher synthesis temperatures suggesting particle agglomeration and greater size distributions [22] [23]. The XRD patterns shown in Figure 1(a) demonstrated 
the formation of the face-centered cubic (FCC) silver crystalline structure in accordance with PDF No. 98-000-0398. The crystallite size of the AgNP, for each synthesis temperature, was calculated using the Debye-Scherrer relationship at the most intense peak by MDI/JADE software, which corresponds to the (111) plane (Table 1) [24] [25] [26] [27]. The obtained values demonstrated an increment in the nanoparticle's crystallite size as synthesis temperatures increased.

CuNPs were also synthesized at temperatures ranging from $155^{\circ} \mathrm{C}$ to $180^{\circ} \mathrm{C}$. However, only the syntheses performed at temperatures above $175^{\circ} \mathrm{C}$ were successful at reducing $\mathrm{Cu}^{2+}$, evidenced by a change of color in the solution from blue to the red-wine [22] [28]. Since the copper standard potential reduction from $\mathrm{Cu}^{2+}$ to $\mathrm{Cu}^{0}$ is $+0.34 \mathrm{~V}$, whereas for silver reduction from $\mathrm{Ag}^{+}$to $\mathrm{Ag}^{0}$ is $+0.80 \mathrm{~V}$, more energy is required to reduce copper nanoparticles [29]. UV-Vis absorption spectra, presented in Figure 2(b), shows a characteristic maximum absorption peak at $653 \mathrm{~nm}$ attributed to copper nanoparticle's plasmon resonance [30]. The X-ray diffraction patterns of Figure 2(a) confirmed that the synthesized nanoparticles exhibited a copper FCC crystalline structure corresponding to PDF No 98-000-0172. The average crystallite size for CuNP was estimated at $14 \mathrm{~nm}$ for nanoparticles synthesized at both temperatures, as is shown in Table 2.

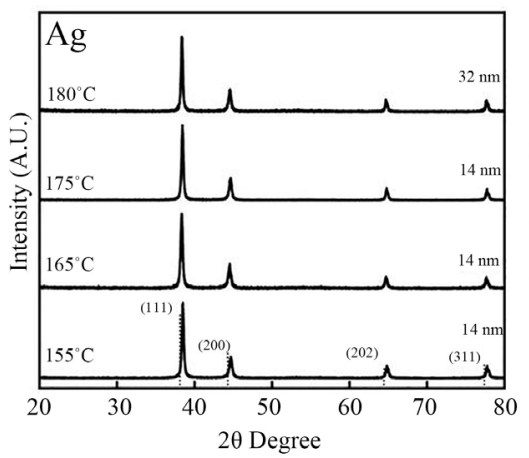

(a)

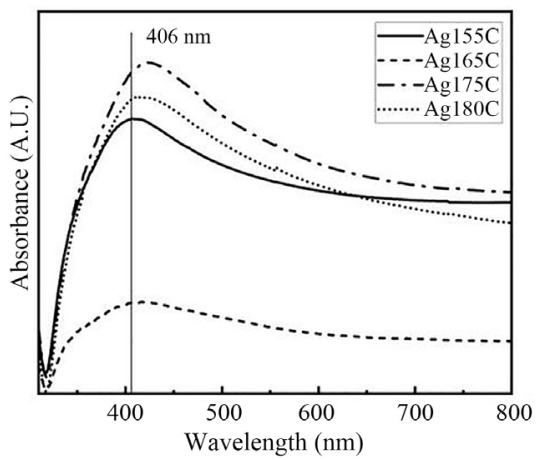

(b)

Figure 1. (a) XRD patterns of $\mathrm{AgNP}$ synthesis from $155^{\circ} \mathrm{C}$ to $180^{\circ} \mathrm{C}$. (b) $\mathrm{UV}-\mathrm{Vis}$ absorption spectra of $\mathrm{AgNP}$ synthesis from $155^{\circ} \mathrm{C}$ to $180^{\circ} \mathrm{C}$ at two minutes heating time.

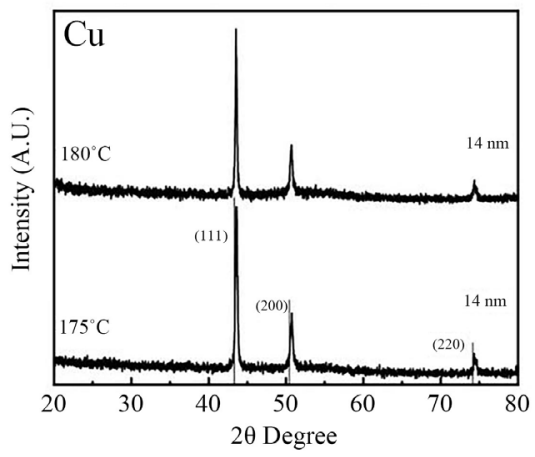

(a)

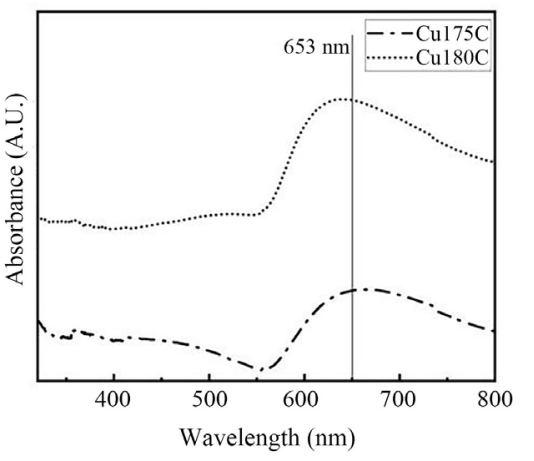

(b)

Figure 2. (a) XRD patterns of CuNP synthesis from $175^{\circ} \mathrm{C}$ to $180^{\circ} \mathrm{C}$. (b) UV-vis absorption spectra of CuNP synthesis from $175^{\circ} \mathrm{C}$ to $180^{\circ} \mathrm{C}$. 
Table 1. Unit-cell parameters and crystallite size of Ag NP for each synthesis temperature evaluated.

\begin{tabular}{ccccccc}
\hline Temperature $\left({ }^{\circ} \mathrm{C}\right)$ & $\mathbf{2} \boldsymbol{\theta}$ & ${ }^{\dagger}$ FWHM & $(\mathrm{h} \mathrm{k} \mathrm{l})$ & ${ }^{\dagger} \mathrm{d}\left(\mathrm{A}^{\circ}\right)$ & ${ }^{\dagger} \mathrm{a}\left(\mathrm{A}^{\circ}\right)$ & ${ }^{\dagger}$ Size $(\mathrm{nm})$ \\
\hline 155 & 38.489 & 0.6106 & $\left(\begin{array}{lll}1 & 1 & 1\end{array}\right)$ & 2.3371 & 4.0480 & $13.8 \pm 1.2$ \\
165 & 38.336 & 0.6100 & $\left(\begin{array}{lll}1 & 1 & 1\end{array}\right)$ & 2.3461 & 4.0635 & $13.8 \pm 1.3$ \\
175 & 38.429 & 0.6104 & $\left(\begin{array}{lll}1 & 1 & 1\end{array}\right)$ & 2.3405 & 4.0539 & $13.8 \pm 1.2$ \\
180 & 38.339 & 0.2615 & $\left(\begin{array}{lll}1 & 1 & 1\end{array}\right)$ & 2.3459 & 4.0633 & $32.2 \pm 3.6$ \\
\hline
\end{tabular}

$\dagger$ These values were obtained using the Debye-Scherrer relationship by MDI/JADE software.

Table 2. Crystallite Size of CuNP determined using Scherrer Equation.

\begin{tabular}{ccccccc}
\hline Temperature $\left({ }^{\circ} \mathrm{C}\right)$ & $\mathbf{2} \boldsymbol{\theta}$ & ${ }^{\dagger}$ FWHM & $(\mathrm{h} \mathrm{K} \mathrm{l})$ & ${ }^{\dagger} \mathrm{d}\left(\mathrm{A}^{\circ}\right)$ & ${ }^{\dagger} \mathrm{a}\left(\mathrm{A}^{\circ}\right)$ & ${ }^{\dagger}$ Size $(\mathrm{nm})$ \\
\hline 175 & 43.565 & 0.6098 & $\left(\begin{array}{lll}1 & 1 & 1\end{array}\right)$ & 2.0758 & 3.5954 & $14.05 \pm 0.7$ \\
180 & 43.549 & 0.6006 & $\left(\begin{array}{lll}1 & 1 & 1\end{array}\right)$ & 2.0765 & 3.5967 & $14.03 \pm 1.4$ \\
\hline
\end{tabular}

$\dagger$ These values were obtained using the Debye-Scherrer relationship by MDI/Jade software.

The previously discussed results from the synthesis of AgNP and CuNP indicate that the smallest nanoparticle size is obtained at a temperature of $175^{\circ} \mathrm{C}$. Consequently, the synthesis of $\mathrm{AgCu}$ bimetallic nanoparticles was performed at $175^{\circ} \mathrm{C}$ in a single 2-minute step. The crystalline structure of the nanoparticles was confirmed by XRD measurements which evidences the presence of both Ag and $\mathrm{Cu}$ structures (Figure 3(a)). In the UV-Vis absorption spectrum (Figure 3 (b)) a redshift in the absorption peak at $443 \mathrm{~nm}$ can be observed, which suggests the formation of an $\mathrm{AgCu}$ bimetallic type nanoparticle [31]. The average crystallite size was estimated at $12.89 \pm 2.00 \mathrm{~nm}$ considering the peak at $2 \theta=$ 38.521 of Ag and $2 \theta=44.761$ of $\mathrm{Cu}$, as it is shown in Table 3.

\subsection{Stability Test of AgNP, CuNP and AgCuNP}

The UV-Vis spectroscopy technique has been widely used to characterize metallic nanoparticles due to the surface plasmon resonance produced by the collective oscillations of the free conductive electrons at the nanoparticle's surface. The electron's vibration mode is related to the size distribution and shape of nanoparticles that produce an optical absorption in the UV-Vis region characteristic of the metal [32] [33] [34] [35] [36] As a result, the stability in the suspension of AgNP, CuNP, and AgCuNP over time, was evaluated by collecting their UV-Vis spectra for 12 days (aging time). UV-Vis measurements of the synthesized nanoparticle solution were done before the washing step (BW), in which nanoparticles are coagulated using 2-propanol. Also, after the washing step $(\mathrm{AW})$, when the previously washed nanoparticles are resuspended in ethylene glycol, and every 24 hours for the following 12 days. Figure 4(a) shows the overlaid UV-Vis spectra of AgNP for the evaluated period, the absorbance peak intensity at $410 \mathrm{~nm}$ stays constant while its width becomes slightly wider over time, as shown in Figure 4(b). The absorbance peak wavelength redshifts from 
410 to $432 \mathrm{~nm}$ suggests an increase in nanoparticle size distribution. In the case of CuNP, the UV-Vis spectra exhibit a characteristic peak at $583 \mathrm{~nm}$ (Figure $5(\mathrm{a}))$, this peak red-shifts to $628 \mathrm{~nm}$ at the end of the 12 days and its plasmon peak intensity decreases (Figure 5(b)). This suggests the decrease of the NP size and the amount of $\mathrm{Cu}^{0}$ by the Ostwald Ripening effect. It also suggests NP surface oxidation, and aggregation-precipitation of CuNP with aging time [37] [38]. The UV-Vis spectral overlay for AgCuNP (Figure 6(a)) shows peaks at $391 \mathrm{~nm}$ and $573 \mathrm{~nm}$ characteristics of the plasmon resonance of AgNP and CuNP, respectively. There were no changes observed in the shape of the spectra and wavelength peaks positions through time, evidencing the stability of the nanoparticles in suspension over these 12 days period (Figure 6(b)).

Table 3. Crystallite Size of AgCuNP determined using Scherrer Equation.

\begin{tabular}{ccccccc}
\hline Temperature $\left({ }^{\circ} \mathrm{C}\right)$ & $\boldsymbol{2} \boldsymbol{\theta}$ & ${ }^{\dagger} \mathrm{FWHM}$ & $(\mathrm{h} \mathrm{K} \mathrm{l})$ & ${ }^{\dagger} \mathrm{d}\left(\mathrm{A}^{\circ}\right)$ & ${ }^{\dagger} \mathrm{a}\left(\mathrm{A}^{\circ}\right)$ & ${ }^{\dagger}$ Size $(\mathrm{nm})$ \\
\hline \multirow{2}{*}{175} & 38.521 & 0.6507 & $\left(\begin{array}{lll}1 & 1 & 1\end{array}\right)$ & 2.3352 & 4.0447 & $12.95 \pm 1.6$ \\
& 44.761 & 0.6707 & $\left(\begin{array}{lll}1 & 1 & 1\end{array}\right)$ & 2.0231 & 3.5041 & $12.83 \pm 1.2$ \\
\hline
\end{tabular}

$\dagger$ These values were obtained using the Debye-Scherrer relationship by MDI/Jade software.

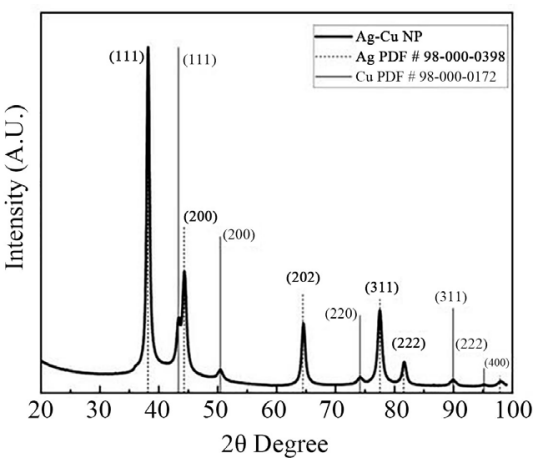

(a)

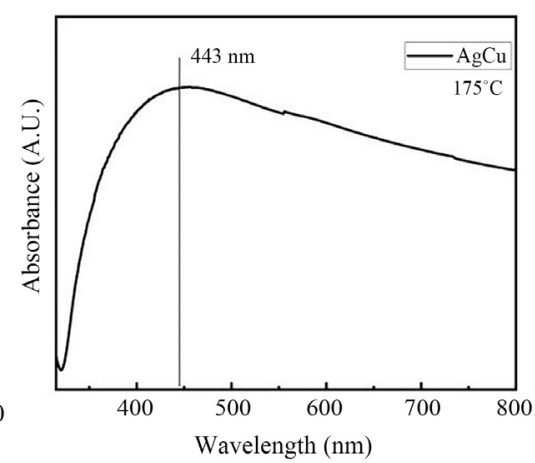

(b)

Figure 3. (a) XRD patterns of AgCuNP synthesis at $175^{\circ} \mathrm{C}$. (b) UV-vis absorption spectra of AgCuNP synthesis at $175^{\circ} \mathrm{C}$.

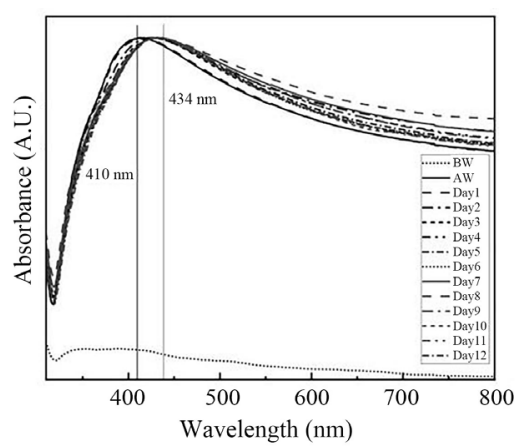

(a)

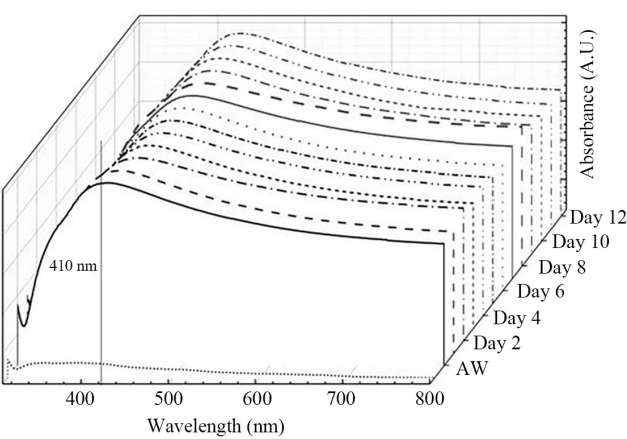

(b)

Figure 4. UV-Vis absorption spectral overlay for AgNP suspension over a period of 12 days. (a) shows a slight red-shift in wavelength through time, while the waterfall plot in (b) shows no changes in the shape of the spectra. 


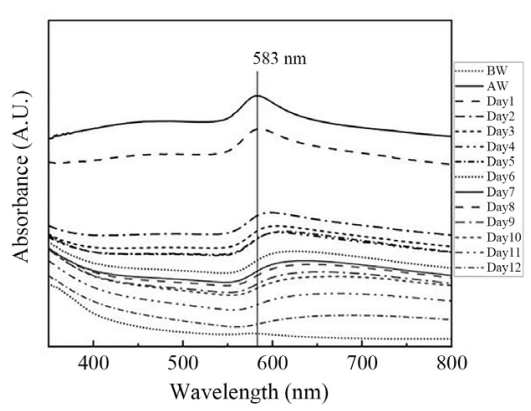

(a)

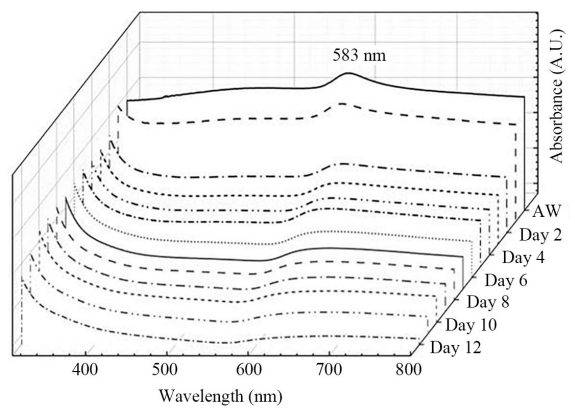

(b)

Figure 5. UV-Vis absorption spectra of CuNP suspension through a period of 12 days. (a) Spectral overlay showing changes in peak height and peak wavelength. (b) Waterfall plot shows changes in spectral shape.

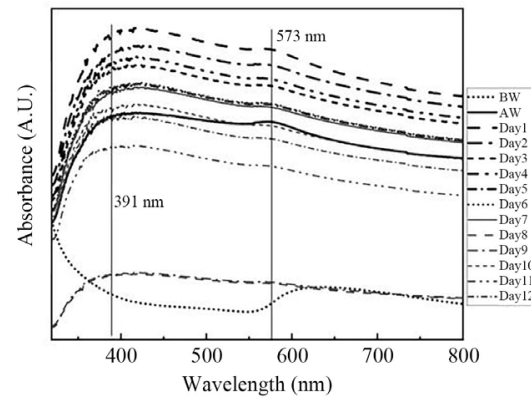

(a)

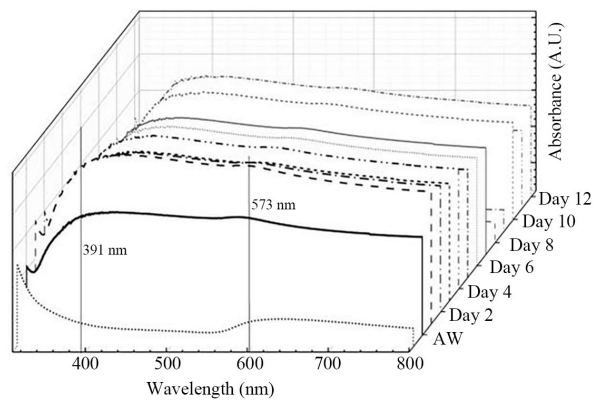

(b)

Figure 6. UV-Vis absorption spectra of AgCuNP suspension through a period of 12 days. (a) Overlaid spectra showing changes in peak height and peak wavelength. (b) Waterfall plot showing changes in spectral shape.

\subsection{HRTEM Analysis}

HRTEM images of the synthesized AgNP are shown in Figure 7 and Figure 8, at $20 \mathrm{~nm}$ and $10 \mathrm{~nm}$ scale bar, respectively. The images reveal the spherical shape of the nanoparticles with an average diameter of $9.7 \pm 4.5 \mathrm{~nm}$ and a narrow particle size distribution as evidenced by the histogram presented in Figure 7(b). The particle size distribution analyses were done using ImageJ software. The ED pattern in Figure 8(b) exhibits the FCC crystalline structure corresponding to Ag, indexed to the (111), (200), (220) and (222) planes. These results confirm the XRD pattern results obtained from the synthesized AgNP. Figure 9(a) and Figure 10(a) correspond to HRTEM images showing spherical crystalline CuNP with an average $7.3 \pm 2.2 \mathrm{~nm}$ diameter. The size distribution analysis, shown in Figure 9(b), reveals that synthesized CuNP were smaller than the synthesized AgNP. The formation of CuNP was demonstrated by the corresponding ED pattern indexed to (111), (200), (220), and (311) planes related to the FCC crystalline structure of $\mathrm{Cu}$, consistent with the XRD analysis. Comparatively, AgCuNP consisted of irregular-shaped nanoparticles (Figure 11(a) and Figure 12(a)) with an average size of $11.7 \pm 3.8 \mathrm{~nm}$ (Figure 11(b)). Figure 12(b) shows the ED pattern results obtained after a mapping control using only carbon film. The 
measurements of the ring's diameter were $0.238 \mathrm{~nm}$ corresponding to miller in$\operatorname{dex}(111)$ from $2 \theta=38.114$ degree for $\mathrm{Ag}$, and $0.203 \mathrm{~nm}$ corresponding to miller index (111) from $2 \theta=43.317$ degree for $\mathrm{Cu}$. The above results fully confirm the successful synthesis of nanoparticles with $\mathrm{Ag}$ and $\mathrm{Cu}$ metal composition.

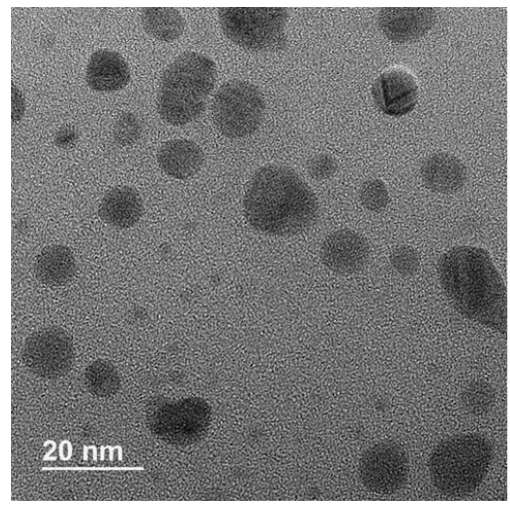

(a)

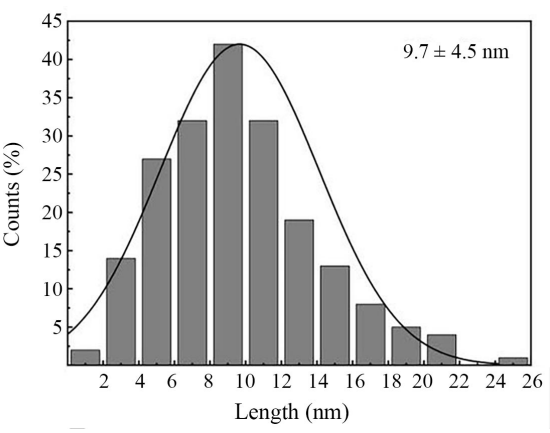

(b)

Figure 7. (a) HRTEM image of AgNP at $20 \mathrm{~nm}$ scale and (b) histogram of nanoparticle size distribution.

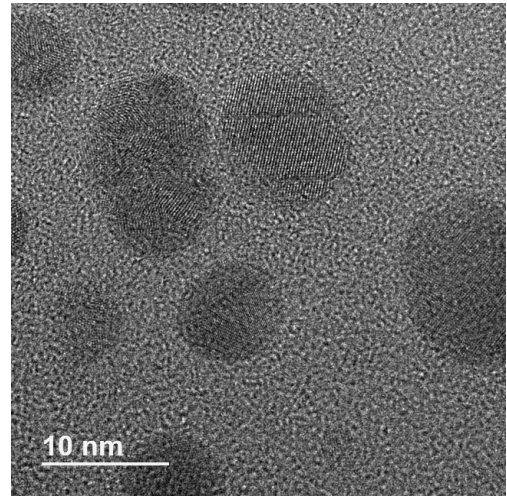

(a)

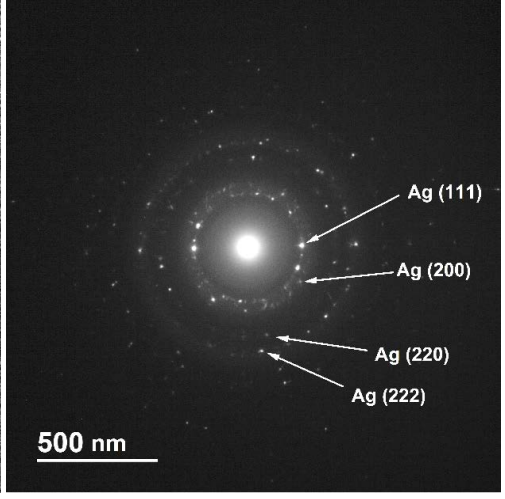

(b)

Figure 8. (a) HRTEM image at $10 \mathrm{~nm}$ scale and (b) ED pattern of AgNP.

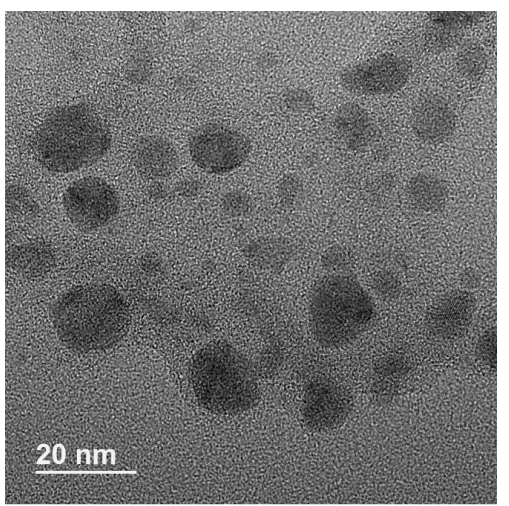

(a)

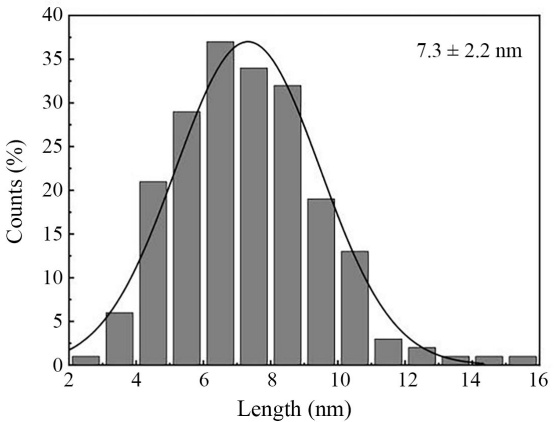

(b)

Figure 9. (a) HRTEM image of CuNP at $20 \mathrm{~nm}$ scale and (b) Histogram of nanoparticle size distribution. 


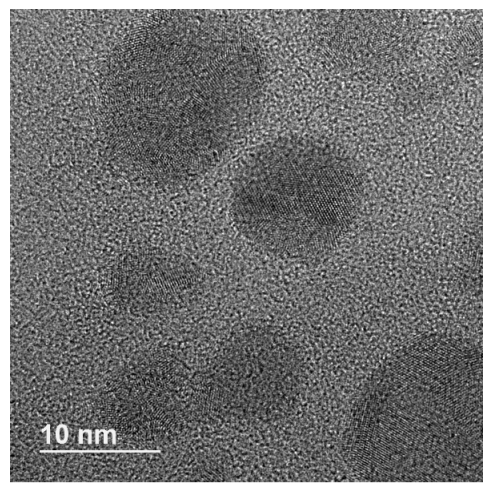

(a)

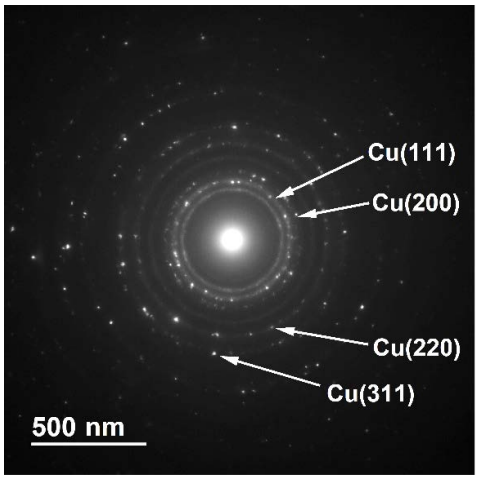

(b)

Figure 10. (a) HRTEM image of CuNP at $10 \mathrm{~nm}$ scale and (b) ED pattern.

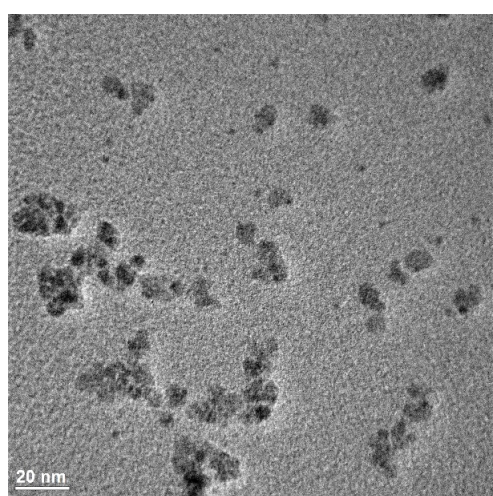

(a)

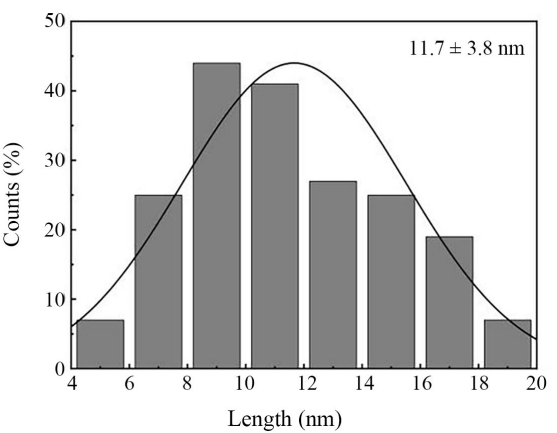

(b)

Figure 11. (a) HRTEM image of AgCuNP at $20 \mathrm{~nm}$ scale and (b) histogram of nanoparticle size distribution.

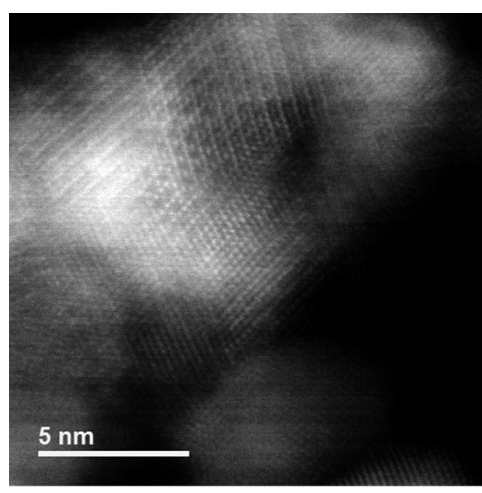

(a)

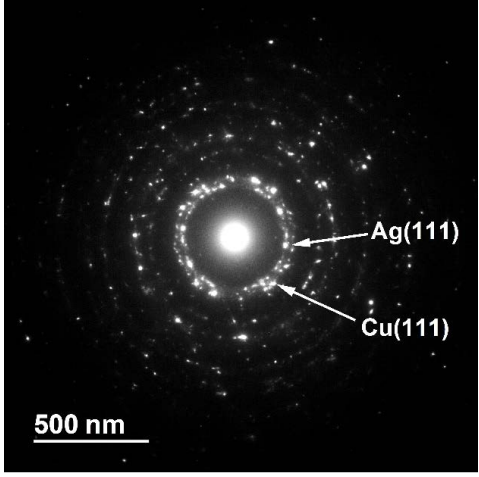

(b)

Figure 12. (a) HRTEM image at $5 \mathrm{~nm}$ scale and (b) ED pattern of AgCuNP.

\subsection{EDX Analysis}

To corroborate the chemical composition and particle distribution of $\mathrm{Ag}$ and $\mathrm{Cu}$ in the synthesized nanoparticles, EDX analysis was performed. Figure 13 shows the elemental mapping of AgCuNP (Figure 13(b)), which revels the homogeneous distribution of $\mathrm{Ag}$ (Figure 13(a)) and $\mathrm{Cu}$ (Figure 13(c)). The EDX elemental analysis demonstrates the presence of $\mathrm{Ag}$ and $\mathrm{Cu}$ in a single particle with 
an atomic percent composition of $51.74 \%$ of $\mathrm{Cu}$ and $48.26 \%$ of $\mathrm{Ag}$ with an $\mathrm{Ag}: \mathrm{Cu}$ atomic ratio around 1:1, which is consistent with the molar ratio used in the synthesis. These results reaffirm the successful formation of an AgCuNP structure through a microwave synthesis time as short as two minutes (Figure 14).

\subsection{Antimicrobial Assay}

The minimum inhibitory concentration (MIC) is the lowest concentration at which an antimicrobial agent is able to inhibit microbial population growth, and the minimum bactericidal concentration (MBC) is the lowest concentration of an antimicrobial agent required to reduce the population at $\geq 99.9 \%$ from the initial inoculum population. Both concentrations are complementary, that is, if a MIC shows inhibition, plating the bacteria onto agar might still result in organism proliferation because the antimicrobial did not cause death, unlike the MBC that it does cause death [20] [39]. The MIC and MBC of AgNP, CuNP and AgCuNP were determined against Gram negative bacteria E. coli and Salmonella, Gram positive $S$. aureus, and a yeast $C$. albicans. The AgCuNP showed greater activity against $E$. coli (Figure 15(a)) with a $\mathrm{MIC}=60 \mu \mathrm{g} / \mathrm{mL}$ and $\mathrm{MBC}=300$ $\mu \mathrm{g} / \mathrm{mL}$. Salmonella (Figure 15(c)) showed more sensitivity in presence of Ag$\mathrm{CuNP}(\mathrm{MIC}=100 \mu \mathrm{g} / \mathrm{mL}$ and $\mathrm{MBC}=100 \mu \mathrm{g} / \mathrm{mL})$ and $\mathrm{AgNP}(\mathrm{MIC}=200 \mu \mathrm{g} / \mathrm{mL}$

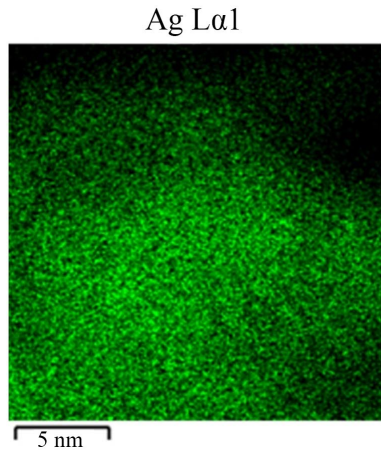

(a)

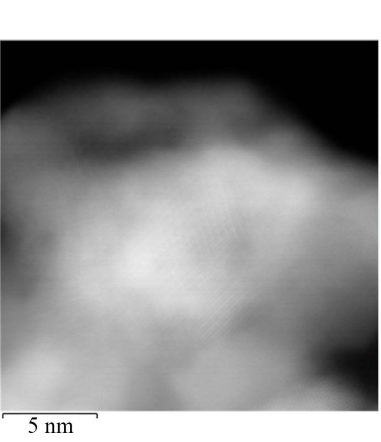

(b)

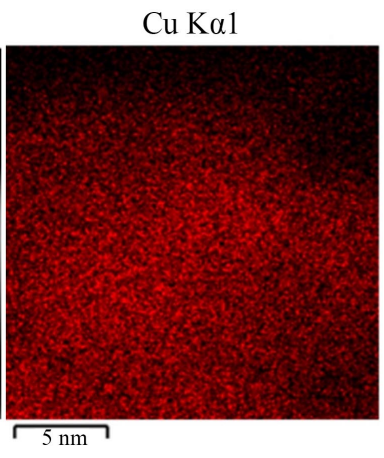

(c)

Figure 13. EDX-mapping of AgCuNP. (a) Ag Lal distribution, (b) Particle analyzed and c) $\mathrm{Cu} \mathrm{Ka} 1$ distribution.

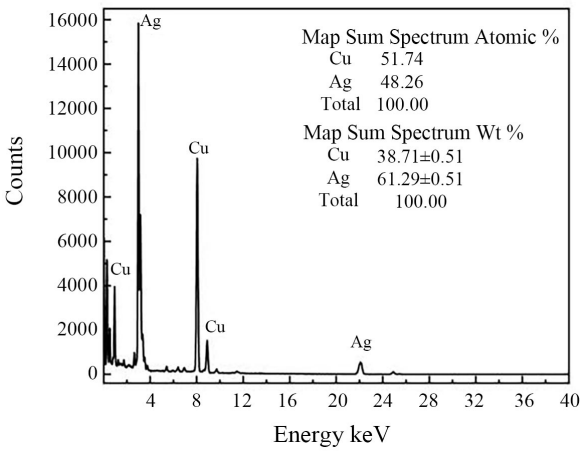

Figure 14. EDX elemental analysis. 


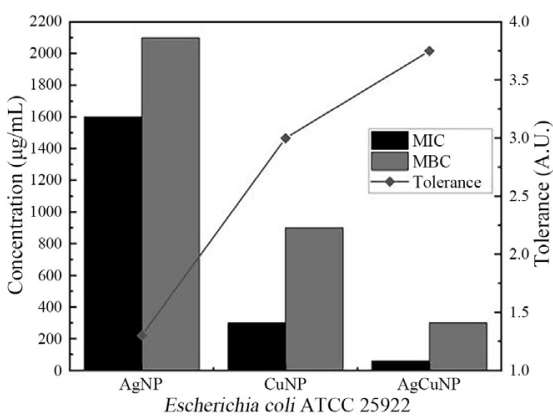

(a)

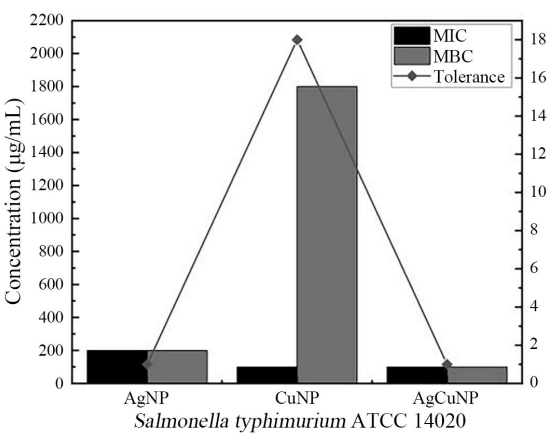

(c)

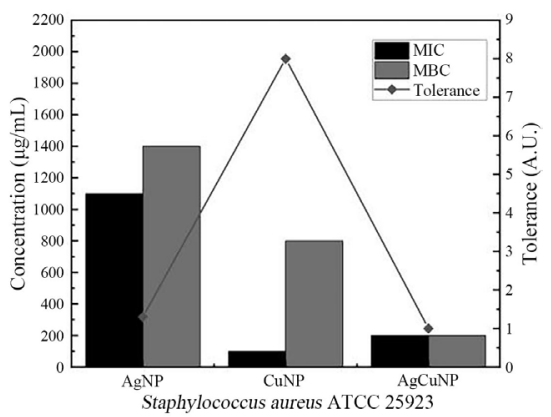

(b)

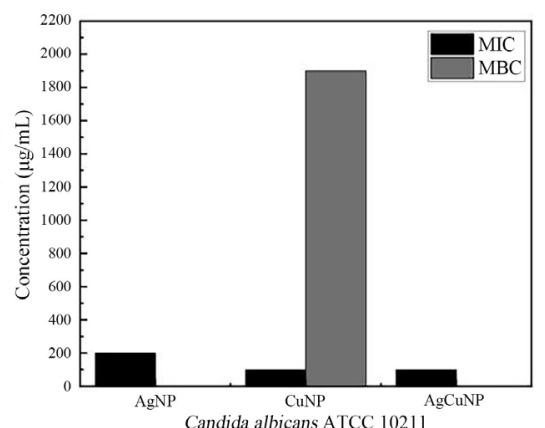

(d)

Figure 15. MIC and $\mathrm{MBC}$ values of $\mathrm{Ag}, \mathrm{Cu}$ and $\mathrm{AgCu} \mathrm{NP}$ against (a) E. coli and (b) $S$. aureus (c) Salmonella and (d) $ґ$. albicans strain.

and $\mathrm{MBC}=200 \mu \mathrm{g} / \mathrm{mL}$ ), where AgCuNP was the best. As same as in the case of Gram-negative bacteria, AgCuNP exhibited the best antibacterial performance against S Aureus (Figure 15(b)), with MIC $=200 \mu \mathrm{g} / \mathrm{mL}$ and $\mathrm{MBC}=200 \mu \mathrm{g} / \mathrm{mL}$. In the case of $C$. albicans, CuNP showed the best results with MIC $=100 \mu \mathrm{g} / \mathrm{mL}$ and $\mathrm{MBC}=1900 \mu \mathrm{g} / \mathrm{mL}$. Whereas, for $\mathrm{Ag}$ and $\mathrm{AgCu}$ NP the $\mathrm{MBC}$ values could not be determined as bacterial growth was observed even at the maximum evaluated nanoparticle concentration $(2200 \mu \mathrm{g} / \mathrm{mL})$. The above results indicate that $\mathrm{AgCuNP}$ are more effective in inhibiting the growth of most of the studied microorganisms. It was evident that Salmonella showed an enhanced vulnerability to these nanoparticles. Differences in the composition and structure of the cell wall of bacteria and yeasts could explain the resistance of the yeast to the effect of nanoparticles. The bacterial cell wall structure is formed by lipopolysaccharides and peptidoglycan layer mainly, the Gram-positive bacteria has a thicker peptidoglycan layer than the Gram negative [40]. In a different way, the yeast cell wall is formed by an inner wall of $\beta, 1-6$ glucan, $\beta, 1-3$ glucan and chitin and an outer protein wall [41]. It has been reported that metallic nanoparticles are able to attach more easily to DNA and proteins [8] [13], which explains why the evaluated yeast was more resistant to the effect of AgNP and AgCuNP, which are more stable than CuNP, hence it would be easier for them to cross the yeast cell wall in an ionic state rather than its metallic state [42]. The MBC/MIC ratio has been denominated Tolerance by May, et al. 2006 [43] and Das, et al. 2017 [5]. When a tolerance value for bacteria is $\geq 16$, the antimicrobial agent is considered 
bacteriostatic, and when the tolerance value is $\leq 4$ the agent is considered bactericidal. Accordingly, a bacteriostatic agent just causes an inhibition of bacterial growth while a bactericidal agent kills bacteria [44] [45]. The tolerance values for $\mathrm{AgNP}, \mathrm{CuNP}$ and AgCuNP were calculated and are shown at the right scale of Figures 15(a)-(c). From the calculated values, AgNP and AgCuNP demonstrated a bactericidal effect against all bacteria, whereas CuNP demonstrated a bactericidal effect against $E$. coli and $S$. aureus and a bacteriostatic effect against Salmonella. The bacteriostatic effect of CuNP can be explained by its antimicrobial mechanism, which has been previously reported in different studies [46]. $\mathrm{Cu}$ NP's antibacterial effect is mainly triggered by the release of copper ions in aqueous solution which lead to the disruption of the bacteria's cell membrane causing cell death.

\section{Conclusion}

This study presents the successful synthesis of $\mathrm{Ag}, \mathrm{Cu}$, and $\mathrm{AgCu}$ nanoparticles via two-minute single-step synthesis using a microwave-assisted heating route at $175^{\circ} \mathrm{C}$. Since silver and copper have different standard reduction potential energy values, several syntheses of $\mathrm{Ag}$ and $\mathrm{Cu}$ nanoparticles at temperatures ranging from $155^{\circ} \mathrm{C}$ to $180^{\circ} \mathrm{C}$ allowed the determination of the optimal synthesis temperature of $\mathrm{AgCu}$ nanoparticles. The synthesized nanoparticles were characterized, and results revealed the spherical shape of $\mathrm{Ag}$ and $\mathrm{Cu}$ nanoparticles with a crystallite size lower than $10 \mathrm{~nm}$. AgCu nanoparticles exhibited an irregular shape and a crystallite size of $12 \mathrm{~nm}$. The atomic percent composition was determined to be $51.74 \%$ of $\mathrm{Cu}$ and $48.26 \%$ of $\mathrm{Ag}$, which correspond to a molar ratio of 2:1.5 of $\mathrm{Ag}: \mathrm{Cu}$, respectively. Further analyses indicated that $\mathrm{AgCu}$ nanoparticles have greater stability and a higher antibacterial effect against $E$. coli, $S$. aureus, and Salmonella typhimurium, generating a bactericidal effect at much lower concentrations than $\mathrm{Ag}$ and $\mathrm{Cu}$ nanoparticles. C. albicans exhibited greater susceptibility to $\mathrm{Cu}$ nanoparticles than $\mathrm{Ag}$ and $\mathrm{AgCu}$ nanoparticles due to rapid oxidation of $\mathrm{Cu}^{0}$ in aqueous environments. These results show the potential of $\mathrm{AgCu}$ nanoparticles to be used in a wide range of applications, from food packaging to wound care technologies. Further investigation that focuses on broadening the antimicrobial spectrum of $\mathrm{AgCu}$ nanoparticles is required to expand its range of possibilities for practical applications.

\section{Acknowledgements}

This work was financially supported by IFN Academic Fellowship of National Science Foundation under Grant No. 01002410. A portion of this work was performed at the National High Magnetic Field Laboratory, which is supported by the National Science Foundation Cooperative Agreement No. DMR-1644779 and the state of Florida. The single crystal X-ray micro-diffractometer was acquired through the support of the National Science Foundation under the Major Research Instrumentation Award Number CHE-1626103. The authors would 
like to acknowledge the support of Mr. Daniel Narvaez and the Center for Nanostructure Characterization at the University of Puerto Rico at Mayaguez.

\section{Conflicts of Interest}

The authors declare no conflicts of interest regarding the publication of this paper.

\section{References}

[1] CDC (2017) Annual Summaries of Foodborne Outbreaks|Foodborne Outbreak Surveillance System. Food Safety.

https://www.cdc.gov/fdoss/annual-reports/index.html

[2] CDC (2020) Foodborne Germs and Illness.

https://www.cdc.gov/foodsafety/foodborne-germs.html

[3] Sharif, M.K., Javed, K. and Nasir, A. (2018) Foodborne Illness: Threats and Control. In: Foodborne Diseases, Elsevier Inc., Amsterdam, 501-523.

https://doi.org/10.1016/B978-0-12-811444-5.00015-4

[4] Beyth, N., Houri-Haddad, Y., Domb, A., Khan, W. and Hazan, R. (2015) Alternative Antimicrobial Approach: Nano-Antimicrobial Materials. Evidence-Based Complementary and Alternative Medicine, 2015, Article ID: 246012. https://doi.org/10.1155/2015/246012

[5] Das, B., Dash, S.K., Mandal, D., Ghosh, T., Chattopadhyay, S., Tripathy, S., et al. (2017) Green Synthesized Silver Nanoparticles Destroy Multidrug Resistant Bacteria via Reactive Oxygen Species Mediated Membrane Damage. Arabian Journal of Chemistry, 10, 862-876. https://doi.org/10.1016/j.arabjc.2015.08.008

[6] Wang, L., Hu, C. and Shao, L. (2017) The Antimicrobial Activity of Nanoparticles: Present Situation and Prospects for the Future. International Journal of Nanomedicine, 12, 1227-1249. https://doi.org/10.2147/IJN.S121956

[7] Sharif, Z. and Mustapha, F.J.Y. (2017) Revisión de métodos de preservación y conservantes naturales para extender la longevidad de los alimentos. Ingeniería Química, 19, 145-153.

[8] Khezerlou, A., Alizadeh-Sani, M., Azizi-Lalabadi, M. and Ehsani, A. (2018) Nanoparticles and Their Antimicrobial Properties against Pathogens Including Bacteria, Fungi, Parasites and Viruses. Microbial Pathogenesis, 123, 505-526. https://doi.org/10.1016/j.micpath.2018.08.008

[9] Sharma, V.K., Yngard, R.A. and Lin, Y. (2009) Silver Nanoparticles: Green Synthesis and Their Antimicrobial Activities. Advances in Colloid and Interface Science, 145, 83-96. https://doi.org/10.1016/j.cis.2008.09.002

[10] Kim, J.S., Kuk, E., Yu, K.N., Kim, J.H., Park, S.J., Lee, H.J., et al. (2007) Antimicrobial Effects of Silver Nanoparticles. Nanomedicine: Nanotechnology, Biology, and Medicine, 3, 95-101. https://doi.org/10.1016/j.nano.2006.12.001

[11] Jin, T. and He, Y. (2011) Antibacterial Activities of Magnesium Oxide (MgO) Nanoparticles against Foodborne Pathogens. Journal of Nanoparticle Research, 13, 6877-6885. https://doi.org/10.1007/s11051-011-0595-5

[12] McNamara, K. and Tofail, S.A.M. (2015) Nanosystems: The Use of Nanoalloys, Metallic, Bimetallic, and Magnetic Nanoparticles in Biomedical Applications. Physical Chemistry Chemical Physics, 17, 27981-27995.

https://doi.org/10.1039/C5CP00831I 
[13] Rai, M. and Shegokar, R. (2017) Metal Nanoparticles in Pharma. Springer, Berlin, $1-493$.

[14] Patra, J.K. and Baek, K.H. (2017) Antibacterial Activity and Synergistic Antibacterial Potential of Biosynthesized Silver Nanoparticles against Foodborne Pathogenic Bacteria along with Its Anticandidal and Antioxidant Effects. Frontiers in Microbiology, 8, 1-14. https://doi.org/10.3389/fmicb.2017.00167

[15] Valodkar, M., Modi, S., Pal, A. and Thakore, S. (2011) Synthesis and Anti-Bacterial Activity of $\mathrm{Cu}, \mathrm{Ag}$ and $\mathrm{Cu}-\mathrm{Ag}$ Alloy Nanoparticles: A Green Approach. Materials Research Bulletin, 46, 384-389. https://doi.org/10.1016/j.materresbull.2010.12.001

[16] Zorraquín-Peña, I., Cueva, C., Bartolomé, B. and Moreno-Arribas, M.V. (2020) Silver Nanoparticles against Foodborne Bacteria. Effects at Intestinal Level and Health Limitations. Microorganisms, 8, 132. https://doi.org/10.3390/microorganisms8010132

[17] Vincent, M., Duval, R.E., Hartemann, P. and Engels-Deutsch, M. (2018) Contact Killing and Antimicrobial Properties of Copper. Journal of Applied Microbiology, 124, 1032-1046. https://doi.org/10.1111/jam.13681

[18] Clinical and Laboratory Standards Institute (2016) Performance Standards for Antimicrobial Susceptibility Testing Supplement M100S.

[19] Elshikh, M., Ahmed, S., Funston, S., Dunlop, P., McGaw, M., Marchant, R., et al. (2016) Resazurin-Based 96-Well Plate Microdilution Method for the Determination of Minimum Inhibitory Concentration of Biosurfactants. Biotechnology Letters, 38, 1015-1019. https://doi.org/10.1007/s10529-016-2079-2

[20] Oquendo-Cruz, A. and Perales-Pérez, O. (2018) Synthesis, Characterization and Bactericide Properties of Pure and Li Doped ZnO Nanoparticles for Alternative Water Disinfection Methods. Journal of Electronic Materials, 47, 6260-6265. https://doi.org/10.1007/s11664-018-6541-x

[21] Murray, P.R. (2014) The Clinician and the Microbiology Laboratory. In: Mandell, Douglas, and Bennett's Principles and Practice of Infectious Diseases, Eighth Edition, Elsevier Inc., Amsterdam.

[22] Jiang, X.C., Chen, W.M., Chen, C.Y., Xiong, S.X. and Yu, A.B. (2011) Role of Temperature in the Growth of Silver Nanoparticles through a Synergetic Reduction Approach. Nanoscale Research Letters, 6, 32.

https://doi.org/10.1007/s11671-010-9780-1

[23] Paramelle, D., Sadovoy, A., Gorelik, S., Free, P., Hobley, J. and Fernig, D.G. (2014) A Rapid Method to Estimate the Concentration of Citrate Capped Silver Nanoparticles from UV-Visible Light Spectra. Analyst, 139, 4855-4861. https://doi.org/10.1039/C4AN00978A

[24] Rani, S., Suri, P., Shishodia, P.K. and Mehra, R.M. (2008) Synthesis of Nanocrystalline $\mathrm{ZnO}$ Powder via Sol-Gel Route for Dye-Sensitized Solar Cells. Solar Energy Materials and Solar Cells, 92, 1639-1645. https://doi.org/10.1016/j.solmat.2008.07.015

[25] Monshi, A., Foroughi, M.R. and Monshi, M.R. (2012) Modified Scherrer Equation to Estimate More Accurately Nano-Crystallite Size Using XRD. World Journal of Nano Science and Engineering, 2, 154-160. https://doi.org/10.4236/wjnse.2012.23020

[26] Chandra, S., Kumar, A. and Tomar, P.K. (2014) Synthesis and Characterization of Copper Nanoparticles by Reducing Agent. Journal of Saudi Chemical Society, 18, 149-153. https://doi.org/10.1016/j.jscs.2011.06.009

[27] Khan, A., Rashid, A., Younas, R. and Chong, R. (2016) A Chemical Reduction Ap- 
proach to the Synthesis of Copper Nanoparticles. International Nano Letters, 6, 21-26. https://doi.org/10.1007/s40089-015-0163-6

[28] Sierra-Ávila, R., Pérez-Alvarez, M., Cadenas-Pliego, G., Comparán Padilla, V., Ávila-Orta, C., Pérez Camacho, O., et al. (2015) Synthesis of Copper Nanoparticles Using Mixture of Allylamine and Polyallylamine. Journal of Nanomaterials, 2015, Article ID: 367341. https://doi.org/10.1155/2015/367341

[29] Greenwood, N. and Earnshaw, A. (1997) Chemistry of the Elements. Elsevier, Amsterdam, 1173-1200. https://doi.org/10.1016/B978-0-7506-3365-9.50034-1

[30] Dang, T.M.D., Le, T.T.T., Fribourg-Blanc, E. and Dang, M.C. (2011) The Influence of Solvents and Surfactants on the Preparation of Copper Nanoparticles by a Chemical Reduction Method. Advances in Natural Sciences. Nanoscience and Nanotechnology, 2, Article ID: 025004. https://doi.org/10.1088/2043-6262/2/2/025004

[31] Li, S., Wei, T., Tang, M., Chai, F., Qu, F. and Wang, C. (2018) Facile Synthesis of Bimetallic Ag-Cu Nanoparticles for Colorimetric Detection of Mercury Ion and Catalysis. Sensors and Actuators, B: Chemical, 255, 1471-1481. https://doi.org/10.1016/j.snb.2017.08.159

[32] Desai, R., Mankad, V., Gupta, S.K. and Jha, P.K. (2012) Size Distribution of Silver Nanoparticles: UV-Visible Spectroscopic Assessment. Nanoscience and Nanotechnology Letters, 4, 30-34. https://doi.org/10.1166/nnl.2012.1278

[33] Mourdikoudis, S., Pallares, R.M. and Thanh, N.T.K. (2018) Characterization Techniques for Nanoparticles: Comparison and Complementarity upon Studying Nanoparticle Properties. Nanoscale, 10, 12871-12934. https://doi.org/10.1039/C8NR02278I

[34] Begum, R., Farooqi, Z.H., Naseem, K., Ali, F., Batool, M., Xiao, J., et al. (2018) Applications of UV/Vis Spectroscopy in Characterization and Catalytic Activity of Noble Metal Nanoparticles Fabricated in Responsive Polymer Microgels: A Review. Critical Reviews in Analytical Chemistry, 48, 503-516. https://doi.org/10.1080/10408347.2018.1451299

[35] Behzadi, S., Ghasemi, F., Ghalkhani, M., Ashkarran, A.A., Akbari, S.M., Pakpour, S., et al. (2015) Determination of Nanoparticles Using UV-Vis Spectra. Nanoscale, 7, 5134-5139. https://doi.org/10.1039/C4NR00580E

[36] Senthil Kumar, P., Grace Pavithra, K. and Naushad, M. (2019) Characterization Techniques for Nanomaterials. In: Nanomaterials for Solar Cell Applications, Elsevier Inc., Amsterdam, 97-124.

https://doi.org/10.1016/B978-0-12-813337-8.00004-7

[37] Barrière, C., Piettre, K., Latour, V., Margeat, O., Turrin, C.O., Chaudret, B., et al. (2012) Ligand Effects on the Air Stability of Copper Nanoparticles Obtained from Organometallic Synthesis. Journal of Materials Chemistry, 22, 2279-2285. https://doi.org/10.1039/C2JM14963J

[38] Singh, M., Sinha, I., Premkumar, M., Singh, A.K. and Mandal, R.K. (2010) Structural and Surface Plasmon Behavior of $\mathrm{Cu}$ Nanoparticles Using Different Stabilizers. Colloids and Surfaces A: Physicochemical and Engineering Aspects, 359, 88-94. https://doi.org/10.1016/j.colsurfa.2010.01.069

[39] Balouiri, M., Sadiki, M. and Ibnsouda, S.K. (2016) Methods for in Vitro Evaluating Antimicrobial Activity: A Review. Journal of Pharmaceutical Analysis, 6, 71-79. https://doi.org/10.1016/j.jpha.2015.11.005

[40] Slavin, Y.N., Asnis, J., Häfeli, U.O. and Bach, H. (2017) Metal Nanoparticles: Understanding the Mechanisms behind Antibacterial Activity. Journal of Nanobio- 
technology, 15, 1-20. https://doi.org/10.1186/s12951-017-0308-Z

[41] Gow, N.A.R. and Hube, B. (2012) Importance of the Candida albicans Cell Wall during Commensalism and Infection. Current Opinion in Microbiology, 15, 406-412. https://doi.org/10.1016/j.mib.2012.04.005

[42] Singh, A., Gautam, P.K., Verma, A., Singh, V., Shivapriya, P.M., Shivalkar, S., et al. (2020) Green Synthesis of Metallic Nanoparticles as Effective Alternatives to Treat Antibiotics Resistant Bacterial Infections: A Review. Biotechnology Reports, 25, e00427. https://doi.org/10.1016/j.btre.2020.e00427

[43] May, J. (1998) Glycopeptide Tolerance in Staphylococcus aureus. Journal of Antimicrobial Chemotherapy, 42, 189-197. https://doi.org/10.1093/jac/42.2.189

[44] Allafchian, A.R. and Jalali, S.A.H. (2015) Synthesis, Characterization and Antibacterial Effect of Poly(acrylonitrile/maleic acid)-Silver Nanocomposite. Journal of the Taiwan Institute of Chemical Engineers, 57, 154-159.

https://doi.org/10.1016/j.jtice.2015.05.015

[45] Vanti, G.L., Kurjogi, M., Basavesha, K.N., Teradal, N.L., Masaphy, S. and Nargund, V.B. (2020) Synthesis and Antibacterial Activity of Solanum Torvum Mediated Silver Nanoparticle against Xxanthomonas axonopodis pv. punicae and Ralstonia solanacearum. Journal of Biotechnology, 309, 20-28.

https://doi.org/10.1016/j.jbiotec.2019.12.009

[46] Quaranta, D., Krans, T., Santo, C.E., Elowsky, C.G., Domaille, D.W., Chang, C.J., et al. (2011) Mechanisms of Contact-Mediated Killing of Yeast Cells on Dry Metallic Copper Surfaces. Applied and Environmental Microbiology, 77, 416-426. https://doi.org/10.1128/AEM.01704-10 